\title{
THE THEORY OF SPACE CONCEPTS RELATED TO FORMULA GREEN OPEN SPACE
}

\author{
Aldrin Yusuf Firmansyah \\ Department of Architecture, Faculty of Science and Technology \\ State Islamic University (UIN) Maulana Malik Ibrahim Malang, \\ East Java, Indonesia \\ e-mail: aldrinfirmansyah@yahoo.co.id
}

\begin{abstract}
The concept of green open space is still stuck on the concept of space-based theory of absolute space by Issac Newton, who see space as a separation between the mass of the building as a container (solid) and open space (void). Meanwhile, the demands of the world's cities today to combine city life with the natural environment in the city increasingly limited land has resulted in the embodiment of innovation of green open spaces, combined with the mass of the building, either vertically, horizontally, multilevel, and a roof garden. Therefore, the thought about the concept of green area calculation shifts related to the building envelope as an instrument to control the development of the building as a 3-dimensional, in the form of an imaginary space by the slope of the field open sky (Sky Exposure Plane / SEP) were measured from a specific point on the surface of the surrounding road. This paper aims to formulate the calculation of green coverage in relation to the SEP. The concept of SEP operationally still only concerned with building setback. This research method is descriptive qualitative in 2 stages. The first step is the influence of the theory of space to green space on the site and the building. The analysis is supported by the classification of urban space. The second step is the calculation formula of green coverage in relation to the SEP by Surabaya city government regulation no. 7, March 23, 1992, so the calculation formulation contextual conditions in Indonesia. The results showed that the formulation of green coverage in relation to the SEP is an instrument to determine the limit on the development of 3 dimensional green space.
\end{abstract}

Keywords: green coverage, sky exposure plane/SEP, theory of space

\section{ABSTRAK}

Konsep ruang terbuka hijau masih terjebak pada konsep teori ruang berbasis ruang mutlak oleh Issac Newton, yang melihat ruang sebagai pemisahan antara massa bangunan sebagai wadah (padat) dan ruang terbuka (void). Sementara itu, tuntutan kota-kota di dunia saat ini untuk menggabungkan kehidupan kota dengan ling- 
kungan alam di kota dengan tanah yang semakin terbatas telah menghasilkan perwujudan inovasi ruang terbuka hijau, dikombinasikan dengan massa bangunan, baik secara vertikal, horizontal, bertingkat, dan roof garden. Oleh karena itu, pemikiran tentang konsep pergeseran perhitungan kawasan hijau terkait dengan selubung bangunan sebagai instrumen untuk mengontrol perkembangan bangunan sebagai 3-dimensi, dalam bentuk ruang imajiner dengan kemiringan langit lapangan terbuka (sky exposure plane/SEP) diukur dari titik tertentu pada permukaan jalan sekitarnya. Tulisan ini bertujuan untuk merumuskan perhitungan cakupan hijau dalam kaitannya dengan SEP. Konsep SEP secara operasional masih hanya peduli dengan kemunduran bangunan. Metode penelitian ini adalah deskriptif kualitatif dalam 2 tahap. Langkah pertama adalah pengaruh teori ruang untuk ruang hijau pada lokasi dan bangunan. Analisis ini didukung oleh klasifikasi ruang kota. Langkah kedua adalah rumus perhitungan cakupan hijau dalam kaitannya dengan SEP oleh peraturan pemerintah kota Surabaya no. 7, 23 Maret 1992, sehingga formulasi perhitungan kondisi kontekstual di Indonesia. Hasil penelitian menunjukkan bahwa rumusan cakupan hijau dalam kaitannya dengan SEP adalah alat untuk menentukan batas pada pengembangan RTH 3 dimensi.

Kata kunci: cakupan hijau, sky exposure plane/SEP, teori ruang

\section{INTRODUCTION}

The existence of the site as part of the space is also still implies a sense of difference and contradiction as the implications of the dichotomy between the mass of the building (figure) and open space (ground), especially regarding the treatment of green open space in the building. This phenomenon is particularly felt in many cities of the world. Cities will play as vital a role in the future as they do today, with more people living in urban areas than in rural. In many cities around the world, the amount of green spaces is rapidly diminished. In order to maintain the balance of urban ecosystems globally, cities must find a way to combine the best of urban life with the best of nature. Around the world, interest in urban green spaces appears to be growing. Many cities are now experimenting with innovative ways of bringing urban greenery into the city, and nowhere more so than in emerging eco-cities. Innovation in urban green spaces are appeared on vertical, multilevel and roof garden structures. These innovation make contemporary urban form, with there are no clear distinct between urban mass and green open space. Meanwhile, the understanding of urban green open space have still based on differentiation between mass and open space. Therefore, the thought about the concept of green area calculation shift related to the building envelope as an instrument to control the development of the building as a 3-dimensional, in the form of an imaginary space by the slope of the field open sky (Sky Exposure Plane / SEP) were measured from a specific point on the surface of the surrounding road. This paper aims to formulate the calculation of green coverage in relation to the SEP. The concept of SEP operationally still only concerned with building setback. 
According to Madanipour (1996) there are gaps and fragmentation understanding of space. Understanding of space is still dominated by problems and conflict perspective review. Globally, the perspective of an overview of the spaces include review of the theory of absolute space, relational space theory and the theory of relativity space.

\section{Thought of Designing Site Based on Absolute Space Theory Approach}

According Madanipour (1996) concept of this kind of thinking is based on the theory of absolute space by Issac Newton who see space as a separation between the mass of the building as a container (solid) and open space as empty space (void). Added by Madanipour (1996) by quoting Zevi (1957) and Van der Laan (1983) state that the present architectural space through the presence of the wall. This wall will create a new space in it that separates the surrounding natural space. This means that the space for urban design thinking that road, field, garden, play area, gardens and all about open spaces is emptiness (void) which appears by limiting or defining the building mass (solid). Each architectural volumes, each structure creates a boundary wall and stop the continuity of space. This clearly proves that every function of the building impact on the emergence of two spaces, namely the internal space defined by building mass itself (solid), and the external space that is defined by the open space (void).

In the design area, the separation between the built form pattern (building mass) and open space (open space) is often used as a good tool to identify a texture and a pattern of spatial (urban fabric), as well as identify problems regularity mass/ urban space that is collected in the theory of figure-ground. According to Zahnd (1999), figure is a term for building mass (usually in the pictures shown in black) and the ground is a term for out of all the space of the building (usually indicated by white color). By analyzing the patterns of texture regions and find the pattern differences, we will get the information that shows the characteristic structure of the region and its environment.

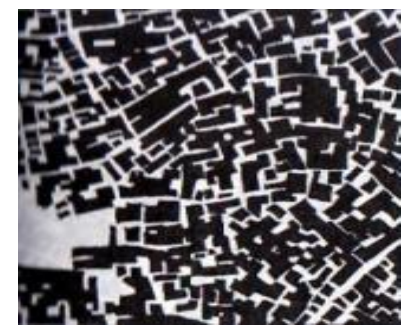

a. The pattern is figureground area of the city of Algiers, Morocco, with regional patterns that are homogeneous

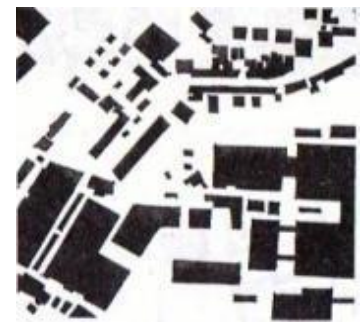

b. The pattern is figureground region of Aachen, Germany, which is heterogeneous

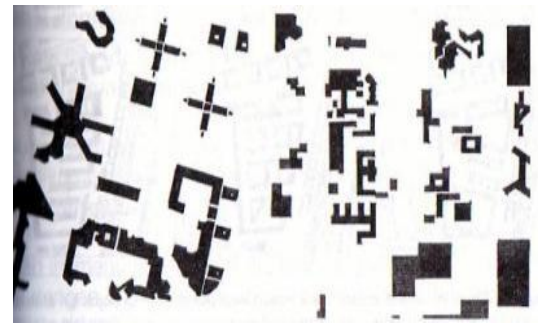

c. The pattern is figure-ground area of Bonn and Hamburg, Germany. Both of these regions have a pattern that is somewhat chaotic

Figure 1. The Figure Ground Patterns of City Source: Zahnd, 1999 

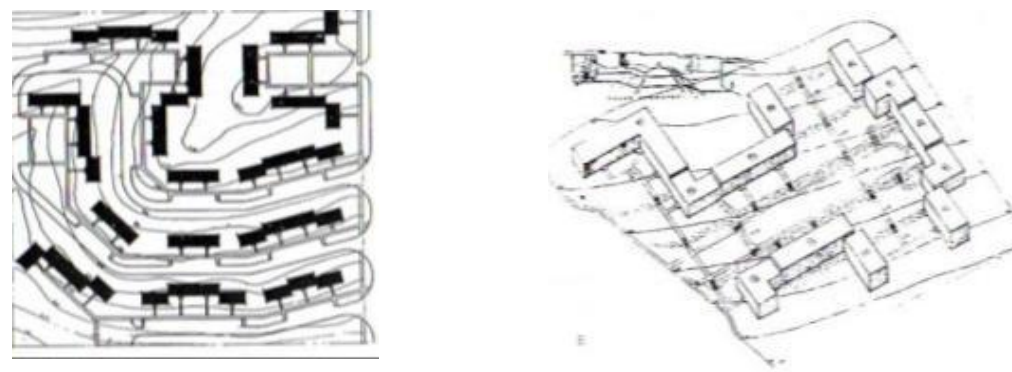

Figure 2. Order in Figure-Ground Mass on Contoured Site Source: De Chiara and Koppelman, 1978

\section{Thoughts of Designing Site Based on Relational Space Theory Approach.}

The theory of relational space have thought the opposite to the theory of absolute space. According thought relational space, space is only a matter of quality position. What is known as the outer object is no more just a matter of sensory representation (sensibility) observer to what constitutes the space. In this case the existence of the type of material also affects the understanding of space, to be supported by the senses and intellectually demanding to be interpreted. Therefore, looking at the room as a simple classification of the material and the separation between the external and internal space as absolute space thinking is a naive.

Related polemic between thinking in absolute space and relational, opinions Jenks (1997) by quoting Graves (1982) about the architecture is more figurative bridging the polemical thinking. This thinking is based that when construction of architectural will be required distinction in the language of its constituent elements. This architectural language should refer to the technical aspects of the implementation that is always parallel with the quality of position or expressions of external parts of the building. Expression of the formation of this space is not just the external impression of the building, but even more as the internalization of the reading between the interior and exterior. An architectural design means unify the expression of the internal and external parts. Expression language outside of the building related to the figurative building and approach the size of the human body (anthropometric). In this regard, we assume that the architecture, engineering and art design plays an important role. Nevertheless, it should be said that not only the architectural components derived from pragmatic purposes, but also refers to the symbol. Architectural elements require this distinction, one against the other, as the language requires a language rules. Without variation among the elements of architecture, will be the removal of anthropometric aspects or figurative meaning. Limiting elements include walls, floors, and roofs, it becomes no wonder why these elements give the similarity in some respects but also can be understood differently. If the floors, walls and roofs viewed differently as an extension of land (ground), it is then the material will give a different look conclusions. The architect must be aware of the difficulties but also the power of figural aspects of design work. If the external aspect of the composition is part of the expanded language of technical internal demand, it can be 
regarded as a resonance between the human mind and nature. Relational space theory approach with the rapid development of technology supported construction and landscape architecture further enables realization of natural green space in the building is not just on the roof alone (roof garden), but also has developed in the form of a wall or a multilevel building as natural green space.
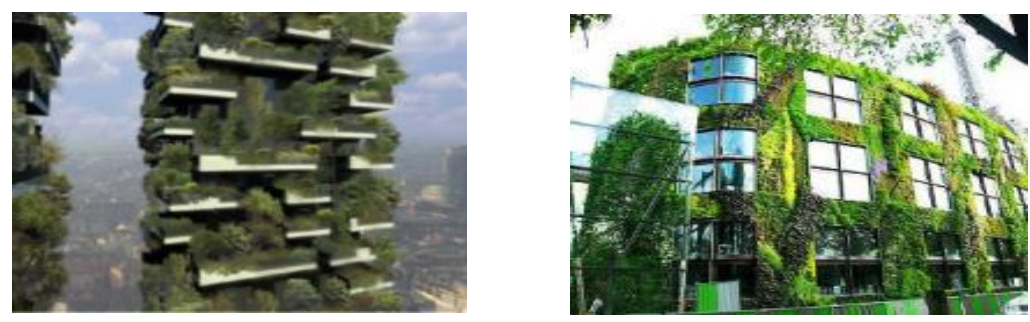

Figure 3. Embodiments of Green Space and Vertical Multi Level Building Source: Byrne and Sipe, 2010

\section{Thoughts of Designing Site Based on Relativity Space Theory Approach}

According to Sutanto (2005) that the design thinking approach to the theory of relativity space is emerging along with the development of Einstein's thinking. In the theory of relativity that time is invisible space so that the space-time outside the conceptual reality of subjective experience of time as a fourth dimension. In this case, as if time or tempo manifested in space like the length, width and height. This means that the idea evolved from the application of the due time as chronological time in the experience of space into space by the time the effects of experience. The idea is to try to challenge the nature of contemporary architecture as static. Tempo as the effect is added to the subjects who experienced space (Figure 4).

Application of designing site based on relativity space theory approach through contemporary idea of tempo in architecture, more open through technological advancement of digital architecture. According to Jenks (1997) by quoting Eisenman (1992) about the architecture in the age of electronic media, the digital architecture of the potential for it to become more expansive in interpreting space, uniting the vertical-horizontal form, figure-ground, interior-exterior through folding architecture ideas. The folded shape not only for achievement in the form curvilinear planimetric projection, but rather as an effective means of presenting well as between functions, shelter, building construction and aesthetics. This means also that the shape of the folds is not associated as a subjective expression of the designer, but rather as an effort to dismantle the separation of function and meaning in a space without the removal of the site sensation. 

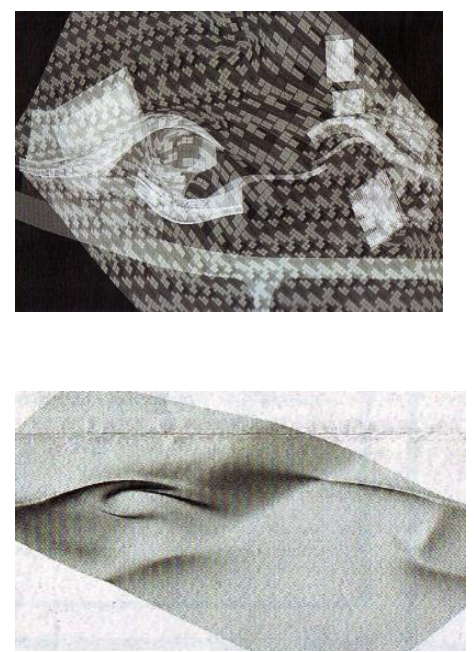

b. Artificial Surface Distortion with Digital Simulation

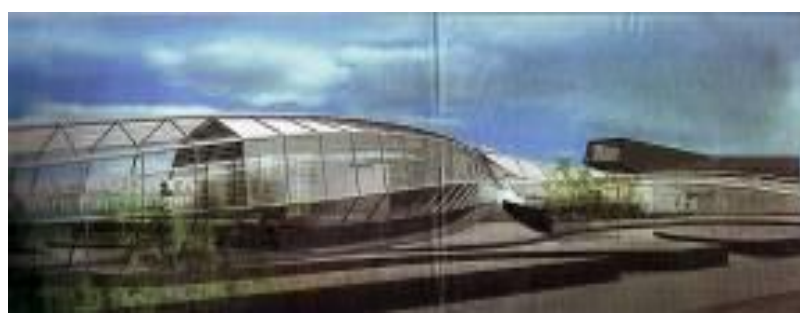

a. Manifestation of The Effect of Time on Outer Space

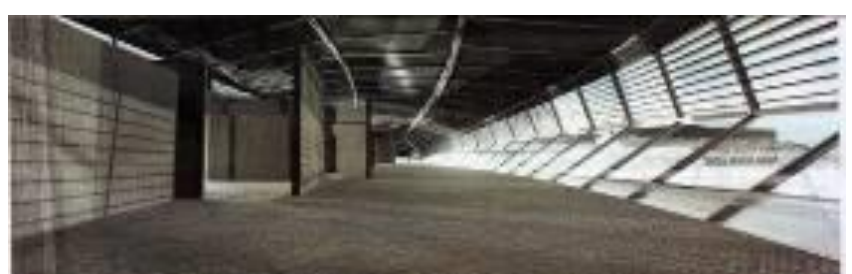

c. Manifestation of The Effect of Time on Inner Space

Figure 4. Surface Contours and Surface Distortion Artifisal, Space and Perspective in The Form of Time in Space on City Projects Parahyangan Culture

Source: Sutanto, 2005

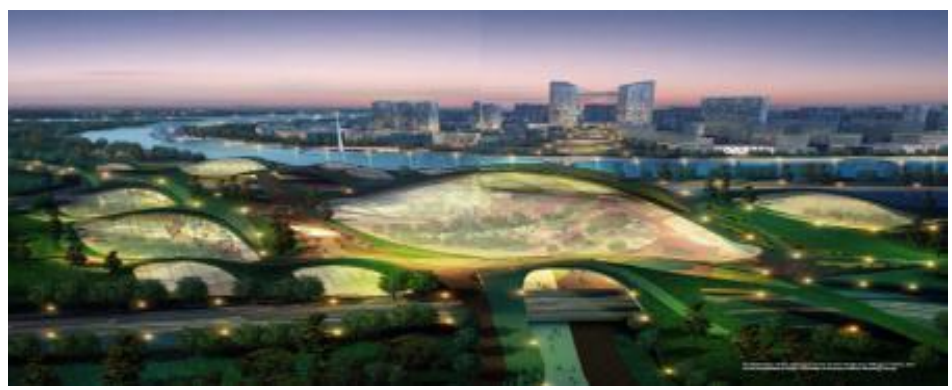

Figure 5. Tianjin Eco-Village in China. Fused Figure and Ground as a Blend of Roofing Materials and Green Open Spaces Source: Byrne and Sipe, 2010

Thoughts on the theory of space to impact the classification concept of urban space, including conducted by Kim and Wentz (2013) who based urban space as a conventional separation of buildings and green space. According to Kim and Wentz building just purely as a mass that does not have a role for the media to contribute to green space, as shown in Figure 6a. Thoughts on theory involving urban space as a medium for building city green spaces such embodiment is realized through UUPR 26 of 2007 on the allocation of green space to support ecological balance, comfort and convenience microclimate activity. Scheme thinking about urban space can be seen in Figure $6 b$. 


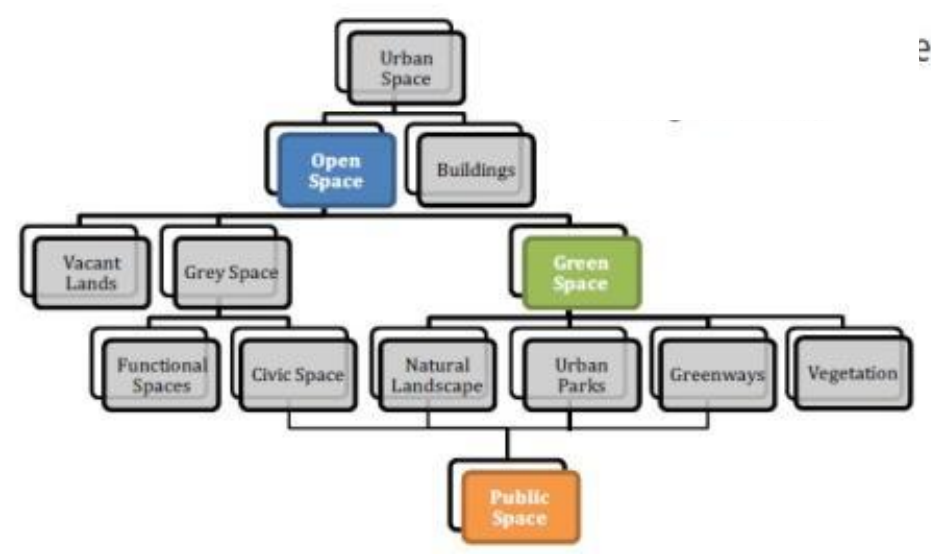

a. Conventional Urban Space Categorization Source: Kim and Wentz, 2013

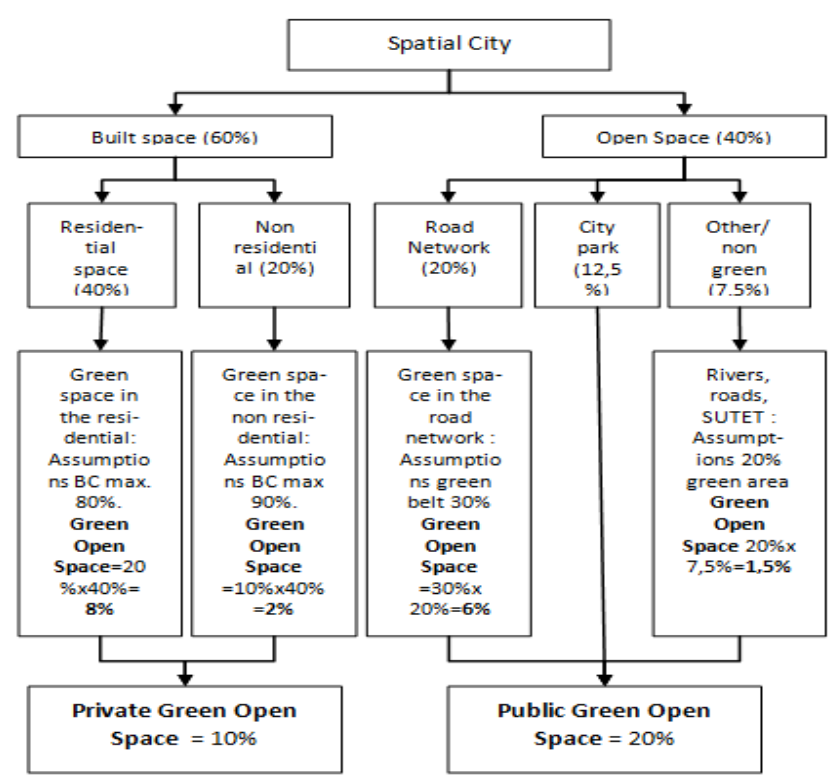

b. Categorization of Urban Space as A Medium for Building City Green Spaces Source: Kurniawati, 2009

Figure 6. Comparison Between Conventional and Contemporary Urban Space

In relation to the calculation of green coverage, conventionally green open space measurements are based on a comparison between the land area of the open (non-mass building) toward the plot area. In the science of urban design, this kind of thinking has a strong link with the term Building Coverage (BC) and Floor Area Ratio (FAR). 


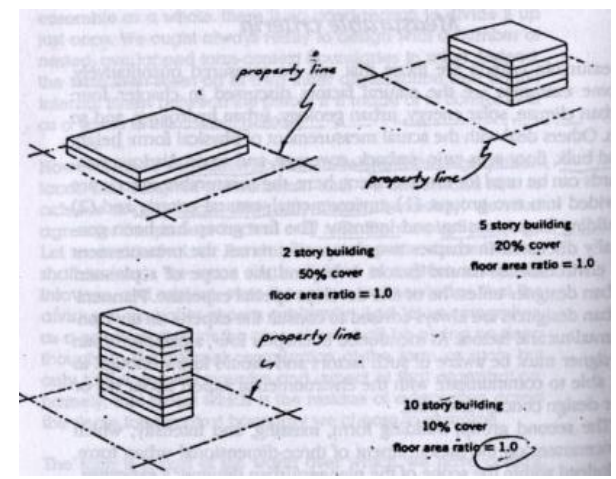

Figure 7. An understanding of Mass and Outer Space as A Solid-Void Source: Shirvani, 1985

Meanwhile, the trend of today's world city pay great attention to green space. This concern is not only for the purpose of preservation needs of the urban environment, but also as a way to increase the attractiveness of town. Many cities are now experimenting with innovative ways of bringing urban greenery into the element of building with there are no clear distinct between urban mass and green space. Therefore, the calculation of the idea of green coverage is also related to the building envelope as an instrument that governs the development of the building in 3 dimensions. Embodiments of a building envelope imaginary space formed Sky Exposure Plane (SEP) which is measured from a specific point on the road surface that surrounds it. Based on the regulation of Surabaya no. 7, March 23, 1992, the rules for SEP heights of low building (up to 4 floors high) and tall buildings I (5-8 floors high), the height $(\mathrm{H})$ of the SEP is $\mathrm{H}=\mathrm{D}$ or the angle of SEP is $45^{\circ}$; while for the second high building (9 floors high above) SEP height is $\mathrm{H}=1.5 \mathrm{D}$, or the angle of SEP is $56^{\circ}$, where D (distance) is the distance as the road to the plot. According to Shirvani (1985) the purpose of building mass control through the building envelope area of the city is to achieve harmony with the function of the building height of buildings, density and mass of the building space, line of sight, lighting and ventilation of the building as well as the prevention of fire hazards.

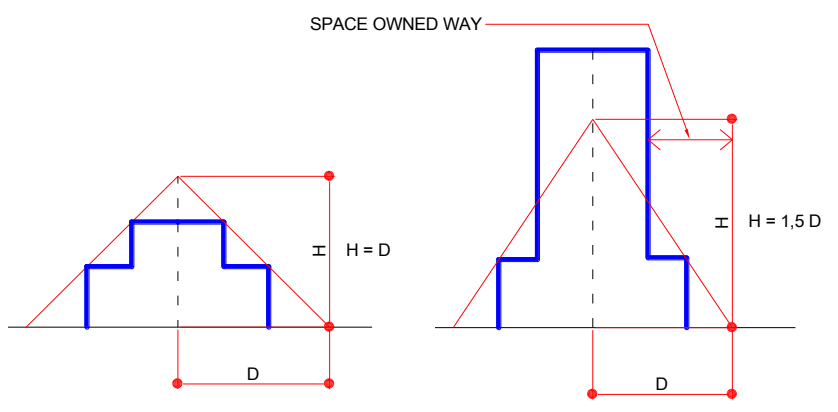

Figure 8. Basic Concept Sky Exposure Plane (SEP). Source: Purwadio, 1994 


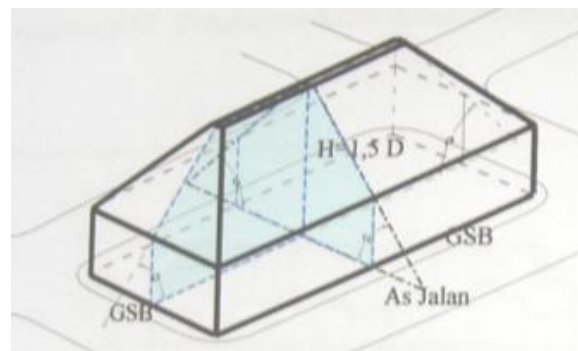

a. Building set-back rules.

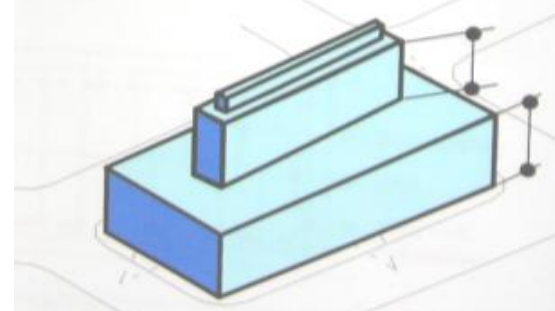

b. Building mass shape formed by the building set-back rules.

Figure 9. Building Set Back Rules and Building Mass Shape Source: Purwadio, 1994

Linkage Sky Exposure Plane (SEP) with lighting and ventilation of buildings realized in its integration with the formulation Angle of Light Obstruction (ALO), which describes the relationship between the building setback, building height and angle of tangency of sunlight fall on the horizontal plane. ALO is the angle of the sun's shadow on a building that is used to determine the building height limit, in relation to exposure to sunlight. The formula to adjust the distance based on the SEP are:

$$
\mathrm{s}=\frac{\mathrm{h}}{\operatorname{tg} \alpha}
$$

Informations: $\mathrm{s}$ = building setbacks (distance to the horizontal direction).

$\mathrm{h}=$ building height at will (distance to the vertical direction).

$\operatorname{tg} \alpha=$ Tangency angle of sunlight falling on the horizontal plane

The relationship between the building setback, building height and angle of tangency of sunlight fall on the horizontal plane can be seen in figure 10. ALO formula is as follows:

$$
\begin{array}{|l|}
\hline \text { h }=\text { h. total }-1,5 \operatorname{tg} . \alpha \\
\hline \text { h. total }=0,5(\mathrm{Jd}+\mathrm{Ls}+\mathrm{Jb}) \operatorname{tg} \alpha \\
\hline
\end{array}
$$

$\mathrm{h}=$ The maximum allowable building height.

h. total $=$ The maximum height $\mathrm{Jd}=$ measuring the distance from the front.

$\mathrm{Jb}=$ distance measured from the rear.

Ls $=$ Width of the side of the building.
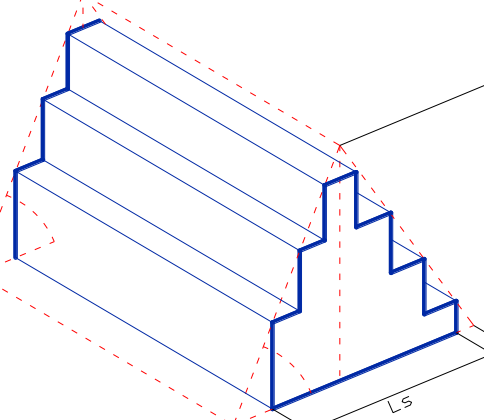

Figure 10. Linkage concept ALO and SEP Source: Purwadio, 1994 
Determination of SEP peak height is closely related to the presence of block planning. According Purwadio (2009), the block is a unit of area that is bounded by the local road and street environment, and subdivided into units smaller regions, called sub-blocks. Sub-block is a unit of area is a collection of plot. The explanations of the classification are:

1. Blocks are regions that have similar functions and characteristics; consists of blocks of large, medium and small.

a. Large blocks: bounded by two collector roads, having a size of 500 x 200 meters.

b. Block with a medium size: bounded by two local roads, have a size of $200 \mathrm{x}$ 100 meters.

c. Small block: bounded by two local streets or roads, have a size of 100 x 100 meters.

2. Sub-block, is part of the block bounded by two neighborhood streets or walkways; have a minimum size of 50 x 50 meters.

3. Lots, is part of the sub-blocks.

\section{THEORY/ RESEARCH METHODS}

The stages of the analysis and the analysis methods, are as in the followings:

1. The first stage of analysis: To compare the influence of the theory of space to the realization of green space on the site and the building. The method of analysis is the influence of the theory of spatial concepts to the realization of green space on the figure-ground mass of buildings and open spaces.

2. The second stage of analysis: To find out calculation formula of green coverage, related to the building envelope. The analysis is restricted to the calculation of green coverage, related to the building envelope as prismatic slope formed by SEP of 2 lane road front and rear side. The method of analysis is to combine the principle of counting SEP integrated with ALO, to formulate the calculation of green coverage in relation to the building envelope. The method of analysis is supported by simulation modeling of the building envelope, and the simulation calculation of the green green coverage.

\section{RESULTS AND DISCUSSION}

\section{Analysis of Space Theory Impact Toward Green Open Space of Building Mass and Site}

Impact-based on site design with absolute space approach is the separation between the internal space of the building and the outside space of the building. Thoughts on space, only in 2-dimensional nature, the built form (figure) and open space (ground). In relation to the understanding of green space, it's obvious manifestation is a part of the exterior of the building space. 
Effect of site-based design approach is the relational space which is the expansion of the external space /natural green space in the building mass. With regard to the figure-ground theory dealed with textural patterns of the masses and open space, this theory is still relevant but must be generated 3-dimensional building components. While the effect of the relativity space approach is the fall of the theory of figure-ground, because there is no separation between the mass of the building and the externl space of the building. Space needs to be taken 3 or 4 dimensional.

\section{Analysis of The Green Area Calculations Related to The Building Envelope as Prismatic Slope Formed by SEP of 2 Lane Road Front and Rear Side}
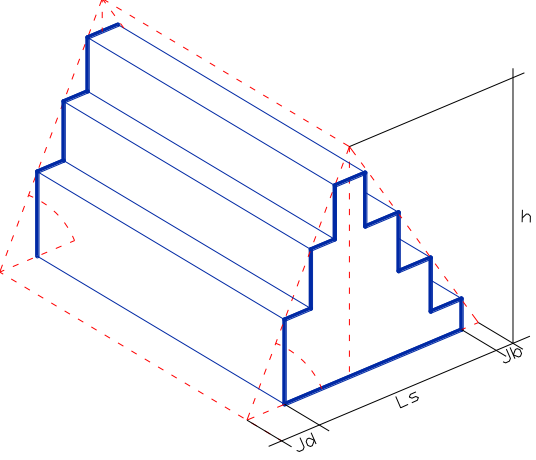

$\mathrm{r}_{\mathrm{d}}=\frac{\mathrm{h}_{\mathrm{d}}}{\sin \alpha}$

$\mathrm{r}_{\mathrm{d}}=\frac{\mathrm{h}_{\mathrm{tot}-\mathrm{h}_{\mathrm{d}}}}{\sin \alpha}=\frac{0,5(\mathrm{Jd}+\mathrm{Ls}+\mathrm{Jb}) \cdot \operatorname{tg} \alpha-\mathrm{Jd} \cdot \operatorname{tg} \alpha}{\sin \alpha},=\underline{0,5(\mathrm{Ls}+\mathrm{Jb}-\mathrm{Jd}) \cdot \operatorname{tg} \alpha}$

$\mathrm{r}_{\mathrm{d}}=\frac{0,5(\mathrm{Ls}+\mathrm{Jb}-\mathrm{Jd})}{\cos \alpha}$

$\mathrm{r}_{\mathrm{b}}=\frac{\mathrm{h}_{\mathrm{b}}}{\sin \alpha}$,

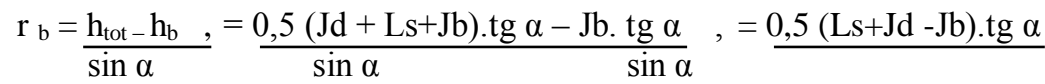

$\mathrm{r}_{\mathrm{b}}=\frac{0,5(\mathrm{Ls}+\mathrm{Jd}-\mathrm{Jb})}{\cos \alpha}$

The area of the green coverage is the sum of the green area of the yard and the green area of the building. By entering equations 6 and 7, the analysis process is to get the formula of green coverage in relation to the building envelope formed by SEP of 2 lane road front and rear sides are:

Green Coverage $(\mathrm{GC})=$ green area of the yard + green area of the building $=($ Total area - Floor area 1$)$ Gyard + green area of the building

$\mathrm{GC}=$ Area $_{\mathrm{Gyard}}+$ Area $_{\mathrm{GFWall}}+$ Area $_{\mathrm{GBW}}+$ Areall $_{\mathrm{GFRoof}}+$ Area $_{\mathrm{GBRoof}}+$ Area $_{\mathrm{GRSide}}+$ Area $_{\mathrm{GLSide}}$ $\mathrm{GC}=\left[(\mathrm{Jd}\right.$-axis $+\mathrm{Ls}+\mathrm{Jb}$-axis $\left.\left.) \mathrm{Ps}-(\mathrm{Ls} \times \mathrm{Pb}) \mathrm{G}_{\mathrm{yard}}\right)\right]+\left[(\mathrm{hd} \times \mathrm{Pb}) \mathrm{G}_{\mathrm{FWall}}\right]+[(\mathrm{hb} \mathrm{x}$ $\left.\mathrm{Pb}) \mathrm{G}_{\mathrm{BWall}}\right]+\left[(0,5(\mathrm{Ls}+\mathrm{Jb}-\mathrm{Jd}) / \cos \alpha) \mathrm{Pb} \times \mathrm{G}_{\mathrm{FRoof}}\right]+[(0,5(\mathrm{Ls}+\mathrm{Jd}-\mathrm{Jb}) / \cos$ 


$$
\begin{aligned}
& \left.\alpha) P b \times G_{\text {BRoof }}\right]+\left[(\text { hd }+ \text { htot }) 0,5 \text { rd. } \cos \alpha+(h b+\text { htot }) 0,5 \text { rb. Cos } \alpha \times G_{L S i d e}\right] \\
& \left.+[\text { hd }+ \text { htot }) 0,5 \text { rd.cos } \alpha+(h b+h \text { tot }) 0,5 \text { rb. } \operatorname{Cos} \alpha \times G_{R S i d e}\right]
\end{aligned}
$$

General information :

$\mathrm{G}_{\mathrm{yard}}$ : Part of green area of yard

GFWall : Part of green area of Front wall

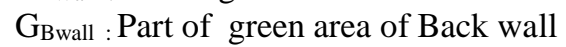

$\mathrm{G}_{\mathrm{FRoof}}$ : Part of green area of Front roof

Remarks parts formula :

$\mathrm{Jd}$ : Measuring the distance from the front

Axis : Distance axis path

Ls : The width of the side buildings

$\mathrm{Jb}$ : Distance measuring from the back
$\mathrm{G}_{\mathrm{BRoof}}$ : Part of green area of Back roof

$\mathrm{G}_{\mathrm{Rside}}$ : Part of green area of Right side

$\mathrm{G}_{\text {Lside : }}$ Part of green area of Left side

Ps : length of site

$\mathrm{Pb}$ : The length of the building

hd : The measured height of the front

$\mathrm{hb}$ : measured height of the rear

htot : The maximum height / peak SEP

Example question:

A building is located in a block, which is flanked by 2 lane road in front and behind, with each lane width is 10 meters. The size of the site has a length of 150 meters and a width of 100 meters. From the edge of the existing site, building setback from the front side is 20 meters, and from the back side is 10 meters. 1 st floor of the building has a length of 100 meters, with the left side of the building coincides with the neighbors, and the right side of the building are free with the access point. The building is designed in the category of low building (4th floor), so that the provisions height $(\mathrm{H})$ of the SEP is $\mathrm{H}=\mathrm{D}\left(\mathrm{SEP}\right.$ angle $\left.=45^{\circ}\right)$. Yard area, has designed green area covering $10 \%$ of the area of the yard. Lack of the amount of greenness area requirements, placed on the area of the building in all areas of the building on the right side, the front half of the inclined plane, and the entire back of the inclined plane. What is the overall green coverage established by the yard and SEP of the site?

Note :

Width of the front road $=10$ meter

Ls $\quad=70$ meter

Width of the back road $=10$ meter

$\mathrm{G}_{\text {yard }}=10 \%$

Ps

$=150$ meter

$\mathrm{G}_{\text {Rside }} \quad=100 \%$

$\mathrm{Pb}$

$=100$ meter

Jd

$=20 \mathrm{~m}+5 \mathrm{~m}=25$ meter

$\mathrm{G}_{\text {Froof }}=50 \%$

$\mathrm{Jb}$

$$
=10 \mathrm{~m}+5 \mathrm{~m}=15 \text { meter }
$$

\section{Solving the Calculation of Green Coverage in The Conventional Way}

Solving the calculation of green coverage in the conventional way can not be done directly, but absolutely requires modeling to find the length of the hypotenuse is formed by the building mass provision of SEP. Based on the calculation of the common way, the extensive green coverage is: 
1. Green coverage of the field sloping front side $=0,5(100 \mathrm{~m} \times 42.43 \mathrm{~m}) ;=2121.5$ $\mathrm{m}^{2}$

2. Green coverage $\mathrm{f}$ the field sloping back side $=100 \mathrm{~m} \times 56,57 \mathrm{~m} ;=5657 \mathrm{~m}^{2}$.

3. Green coverage right side $=(25 \mathrm{~m}+55 \mathrm{~m}) \times 30 \mathrm{~m} \times 0,5)+(15 \mathrm{~m}+55 \mathrm{~m}) \times 40 \mathrm{~m} \times 0,5$; $=2600 \mathrm{~m}^{2}$.

4. Green coverage of the yard $=[(150 \times 100)-(100 \times 70)] \times 10 \%=800 \mathrm{~m}^{2}$.

The total green coverage $=2121.5 \mathrm{~m}^{2}+5657 \mathrm{~m}^{2}+2600 \mathrm{~m}^{2}+800 \mathrm{~m}^{2} ;=\mathbf{1 1 1 7 8 . 5} \mathrm{m}^{2}$

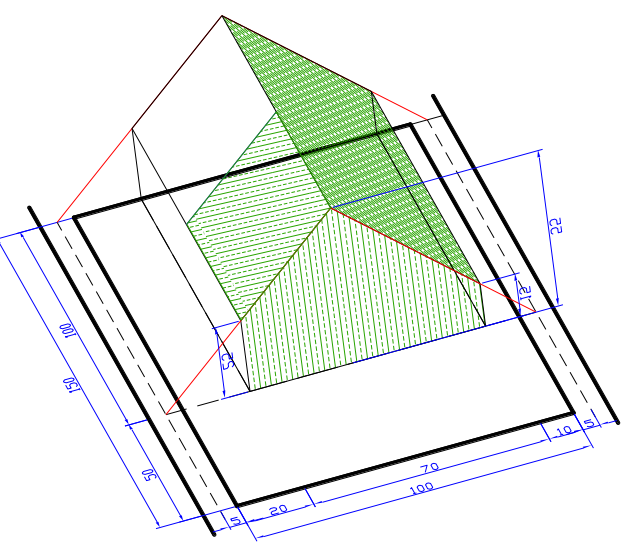

Figure 11a. Modeling of Buildings from the Front Angle

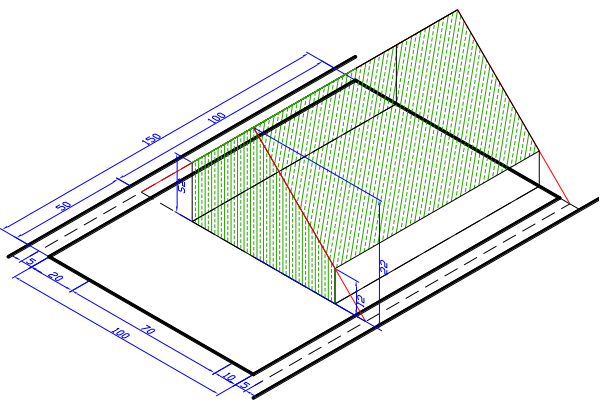

Figure 11b. Modeling of Buildings From The Rear Corner

Figure 11. Modeling The Building of Example Problems Source: Documentation of the author, 2014

2. Solving the calculation of the slope of the green coverage with formula Prismatic building formed by SEP of 2 lane road front and rear side.

$$
\begin{array}{ll}
\text { h. total } & =0.5(\mathrm{Jd}+\mathrm{Ls}+\mathrm{Jb}) \operatorname{tg} \alpha ; \\
& =0.5(25+70+15) \operatorname{tg} 45^{0} ;=55 \mathrm{~m} \\
\text { hd } & =\mathrm{Jd} \cdot \operatorname{tg} \alpha,=25 \operatorname{tg} 45^{0} ;=25 \mathrm{~m} \\
\mathrm{hb} & =\mathrm{Jb} \cdot \operatorname{tg} \alpha,=15 \operatorname{tg} 45^{0} ;=15 \mathrm{~m} \\
\mathrm{r}_{\mathrm{d}} & =\frac{0,5(\mathrm{Ls}+\mathrm{Jb}-\mathrm{Jd})}{\cos \alpha} \quad ;=0,5(70+10-20) / \cos 45^{\circ}=30 / 0,71 ;=42,25 \mathrm{~m} \\
\mathrm{r}_{\mathrm{b}} & =\frac{0,5(\mathrm{Ls}+\mathrm{Jd}-\mathrm{Jb})}{\cos \alpha} \quad ;=0,5(70+20-10) / \cos 45^{\circ}=40 / 0,71 ;=56,34 \mathrm{~m}
\end{array}
$$

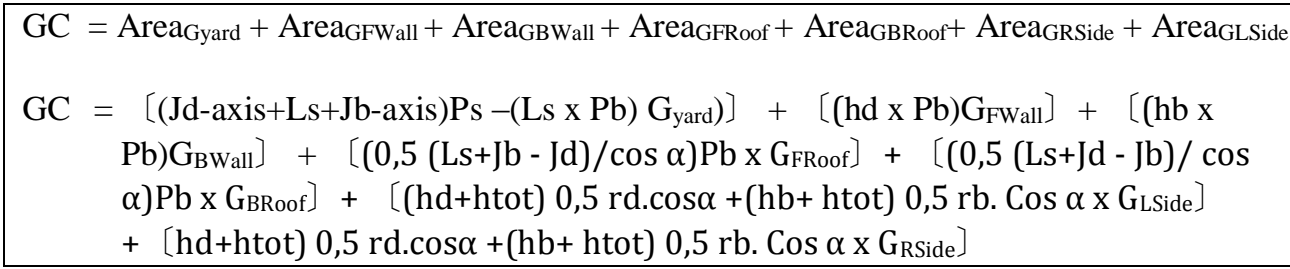




$$
\begin{aligned}
\mathrm{GC}= & {[(20+70+10) 150-(70 \times 100) \times 10 \%]+0+0+\left[\left(0,5(70+10-20) / \cos 45^{0}\right) 100 \times\right.} \\
& 50 \%]+\left[\left(0,5(70+20-10) / \cos 45^{0} \times 100 \%\right]+0+[(25+55) \times 42,25 \times 0,5 \cos \right. \\
& \left.\left.45^{0}+(15+55) \times 0,5 \times 56,34 \cos 45^{0} \times 100 \%\right]\right] \\
\mathrm{GC}= & {[(100 \times 150)-7000) \times 0,1]+0+0+[(0,5 \times 60) / 0,71) 100 \times 0,5]+\lceil(0,5 \times} \\
& 80) / 0,71) 100 \times 1]+0+[(80 \times 42,25 \times 0,5 \times 0,71)+(70 \times 0,5 \times 56,34 \times \\
& 0,71) \times 1] \\
\mathrm{GC}= & {[8000 \times 0,1]+0+0+[42,25 \times 100 \times 0,5]+[56,57 \times 100 \times 1]+0+} \\
\mathrm{GC}= & 1200+1400] \\
\mathrm{GC}= & 800+0+0+21178,5 \mathrm{~m}^{2}
\end{aligned}
$$

\section{CONCLUSION}

Search thoughts of the architectural design space in which based on the site, either through absolute space theory, relational and relativity showed that the presence of natural green space is an important part of architectural design embodiment. Through the approach of relational space and relativity theory, it can be found that the natural green space can be expanded on building components horizontally or vertically; either through a component of floor, wall, roof or multilevel form. The consistency of the reading of the figure-ground mass of the building and opening of a two-dimensional space needs to be refuted. It also meant the opening of new horizons to include green space in the building through the building envelope as an instrument to regulate the building mass is 3 dimensional. It is very supportive of the forms of contemporary cities have limited availability of land for green space and increased damage to the ecosystem. By limiting the study to calculation of the green coverage of building envelope as prismatic slope formed by SEP of 2 lane road front and rear side, it is necessary to further research on the calculation of green coverage associated with the building envelope by SEP as the arrangement of the blocks in the direction of the vertical mass. Calculations also need to involve elements of ecological consumption as a proportionality between the increase in the number of users (people, vehicles, increased environmental contaminants) to the oxygen availability of green open space.

\section{REFERENCES}

Byrne, J. and Sipe, N. (2010), Green and Open Space Planning for Urban Consolidation - A review of the literature and best practice, Urban Research Program Issues Paper 11 March 2010, Griffith University Brisbane, ISBN 978-1-921291-96-8.

De Chiara, J. and Kopelman, L. E. (1978), Standar Perancangan Tapak, Erlangga, Jakarta.

Jenks, C. (1997), Theories and Manifestoes of Contemporary Architecture, Academy Editions, Baffins Lane, Chicester, England, ISBN 0-471-97687-3. 
Kim, W. K. and Wentz, E. A. (2013), Understanding Urban Open Space with A Green Index: How Urban Open Spaces Make A Desert City A Livable City, School of Geographical Sciences and Urban Planning Arizona State University, <Http://www.caplter.asu.edu/docs/symposia/symp2010/Kim_ Wentz.pdf> (Accessed on July 12, 2013).

Kurniawati, W. (2009), Kota Sebagai Tempat Festival Dua Musim, Proceeding for Seminar Nasional Cities 2009, Menuju Ruang Perkotaan Yang Berkelanjutan, Berdaya Saing dan Berotonomi, Pogram Studi Wilayah dan Kota, Fakultas Teknik Sipil dan Perencanaan, ITS, Surabaya.

Madanipour, A. (1996), Design of Urban Space: An Inquiry into A Socio-Spatial Process, John Wiley and Sons, Baffins Lane, Chicester, England, ISBN 0471-96673-8.

Zhand, M. (1999), Perancangan Kota Secara Terpadu: Teori Perancangan Kota dan Penerapannya, Penerbit Kanisius, Yogyakarta, ISBN 979-672-443-X.

Purwadio, H. (1994), Studi Penataan Bangunan Ditinjau dari Perancangan Kota, Studi Kasus Jl. Kertajaya, Surabaya, Research Report, ITS, Surabaya.

Purwadio, H. (2009), Pengembangan Blok Pada Kumpulan Kaveling Yang Potensial Berubah Bentuk. Studi Kasus: Blok di Koridor Jl. Kertajaya Surabaya, Proceeding for Seminar Nasional Cities 2009, Menuju Ruang Perkotaan Yang Berkelanjutan, Berdaya Saing dan Berotonomi, Pogram Studi Wilayah dan Kota, Fakultas Teknik Sipil dan Perencanaan, ITS, Surabaya.

Shirvani, H. (1985), The Urban Design Process, Van Nostrand Reinhold Company, New York, ISBN 0-442-28064-5.

Sutanto, Y. (2005), Arsitektur+Tempo, Harian Kompas, Jakarta, 15 April 2005. 
Firmansyah: THE THEORY OF SPACE CONCEPTS RELATED TO FORMULA GREEN OPEN SPACE

This page intentionally left blank 